\title{
Trade Between East and West Pakistan at World Prices, 1960/61-1969/70
}

by

\section{G.M. RADHU*}

The costs and prices of the commodities traded between East and West Pakistan are an aspect of interwing trade. It has been argued that dometically produced goods often involved greater costs of production and higher prices and therefore imports from one region to the other have been higher priced than similar goods from overseas. However the extent of the price differential between the domestic and world market varies from commodity to commodity because of the unequal degree of protection or subsidy given by the Government. In other words the implicit exchange rate is not the same for all commodities and it differs considerrably between different goods.

This paper is an exercise to derive the value of interwing trade in terms of world prices i.e., the commodities traded between the two regions are evaluated at the prevailing world prices instead of their actual domestic prices. Since the variations between the domestic prices and the world prices are different for different commodities entering interwing trade, it seems appropriate to determine the value at world prices separately for each commodity.

The above approach, however, presents some difficult problems. Many of the commodities traded between the two wings had several varieties of varying quality, design and brand etc., with significant price differentials. International prices for all the varieties are difficult to obtain. Besides the available commodity classification of interwing trade is not sufficiently detailed and in many cases an article does not represent a single commodity or even an aggregate of fairly homogenous commodities.

Given the limitation of the data, the following methodology was adopted for estimating the value of interwing trade in world prices. First we selected those commodities which were common in interwing trade and Pakistan's exports i.e., those commodities which one region exported to the other region as well as to foreign countries. There were a number of such commodities but some of them were not comparable because, in the interwing trade statistics, the commodity classification was not as detailed and comprehensive as in the foreign trade statistics of Pakistan, However, some commodities were fairly comparable and easily identifiable; such as tea, gunny bags,

*The author is a Research Economist at the Pakistan Institute of Development Economics. The author is thankful to Mr. Maudud Mirza for computational assistance. 
- gunny cloth, raw cotton, cotton yarn and cement. These commodities constituted a very large part of the trade between the two wings. For these commodities we used the unit f.o.b. value (at Karachi or Chittagong) as the competi- $\int$. tive world price. In case any of these commodities had more than one variety, with a price difference, we applied the average unit value.

Next, we dealt with those primary commodities which were not given any export subsidy or bonus, but which entered interwing trade. These were identified as rice, wheat, gram and other grains. Coarse rice was a major item in interwing trade and large quantities were exported from West Pakistan to East Pakistan. East Pakistan imported coarse rice from foreign countries also and so c.i.f. values (at world prices) were available [7]. To obtain unit f.o.b. value we deflated the c.if. figures by 5 percent to allow for freight and insurance. ${ }^{i}$

-Wheat, gram and other grains were relatively less important in interwing trade. Since these three commodities were not given any subsidy or bonus, their domestic prices were assumed as equivalent to world prices. In some empirical work done $[2,8]$ f.o.b. prices have been approximated by the amount of export subsidy, therefore, zero subsidy implies (according to this approximation) that domestic price is equivalent to world price. Also Nurul Islam [2] has pointed out that the implicit exchange rate for foodgrains is the official exchange rate because foodgrains are not only imported at the official exchange rate but also are imported duty free.

The remaining commodities in interwing trade were broadly divided in two categories (a) primary commodities (b) manufactured goods. For these commodities we approximated the differential between the domestic price and world price by the amount of subsidyloriginating from the export bonus scheme. This might, somewhat, under-state the amount of subsidy or price differential, because in addition to the export bonus there were other export incentives such as export performance licensing and exemption from indirect taxes. However; the crucial instrument in the export promotion strategy was the export bonus scheme. When the scheme was introduced in 1959, there were several bonus rates, but in general the primary goods were given (with some exceptions) 20 percent and manufactured goods 40 percent bonus with the important exception of jute and cotton. Jute manufactures were given 20 percent and cotton goods 30 percent. In 1964 all bonus rates were reduced to two basic rates i.e., 30 per cent and 20 per cent. In 1967, however, the bonus rates were raised to 40 per cent for manufactured goods and 30 percent for primary and other goods. Using these bonus rates we derived the world prices for the remaining primary and manufactured goods, in the following way.

$$
\begin{aligned}
& \mathbf{P}_{\mathbf{d}}=\mathbf{P}_{\mathbf{w}}(1+\mathrm{rb}) \\
& \mathbf{P}_{\mathbf{w}}=\frac{\mathbf{P}_{\mathbf{d}}}{(1+\mathrm{rb})} .
\end{aligned}
$$

where

$$
\begin{aligned}
& \mathbf{P}_{\mathbf{d}}=\text { domestic price } \\
& \mathbf{P}_{\mathbf{w}}=\text { world price (f.o.b) } \\
& \mathbf{b}=\text { bonus rate } \\
& \mathbf{r}=\text { rate of premium on the bonus }
\end{aligned}
$$

${ }^{2}$ This 5 percent rate was used by Dr. Nurul Islam in [1]. Also this seems to be the practice with the Pakistan Tariff Commission. 
During the years of the export bonus scheme the premium on bonus vouchers widely fluctuated but it averaged around 150 per cent of the face value. This rate was employed in various research works $[3,8]$.

- In the case of first category i.e. primary commodities, the above approach seems appropriate because the major exports of Pakistan were primary commodities, therefore the domestic prices of the primary commodities were largely determined by the price of foreign exchange received by exporters.

In the case of the second category, i.e. manufactured goods, however, the above procedure might somewhat understate the price differentials. This is because some of the manufactured goods included in this category were import competing goods, and import restrictions presumably raised their domestic prices substantially above the world prices. Therefore even after deflating domestic prices by the amount of the export bonus there might be a slight overstatement of the world prices for some of the manufactured goods.

Jute and cotton manufactures (n.e.s.) were considered separately from the other manufactured goods partly because they had different bonus rates, and partly because of their importance in interwing trade.

A distinction was made in interwing trade between 'Pakistani merchandise' and 'Foreign merchandise'. Pakistani merchandise comprised of all goods / that were produced or manufactured in Pakistan. They accounted for more than 95 per cent of the total interwing trade. Foreign merchandise referred to goods first imported into Pakistan from foreign countries and then exported to the other region. They accounted for less than 5 per cent of the interwing trade. Thus our analysis is confined to 'Pakistani merchandise'. However, for a rough idea, we have given a separate table showing the balance of trade on foreign merchandise. In the absence of a suitable deflator we have given the balance on 'Foreign merchandise' at the actual (undeflated) prices.

Interwing trade statistics were recorded on a c.i.f. basis, therefore the published data included domestic prices plus freight and insurance charges. To obtain the values at domestic prices for the purpose of our present inquiry we deflated the c.i.f. values to an extent of 5 per cent.

The following table gives a comparison of the interwing trade at domestic and world prices, both converted into dollars at the prevailing official rate of exchange. This shows that during the 10 years period from 1960/61 to 1969/70. West Pakistan had a favourable trade balance of U.S. $\$ 977$ millions at domestic prices and US $\$ 767$ millions at world prices. This indicates that West Pakistan's favourable trade balance with East Pakistan at world prices was about 21 per cent less than at the domestic prices. The above figures do not include trade balance on account of foreign merchandise 
TABLE I

INTERWING EXPORTS

(in thousand dollars)

\begin{tabular}{l|c|c|c|c|c|c}
\hline & \multicolumn{3}{c|}{ At domestic price } & \multicolumn{3}{c}{ At world price } \\
\cline { 2 - 7 } & Yest Pakistan & East Pakistan & Balance & West Pakistan & East Pakistan & Balance \\
\hline & $(1)$ & $(2)$ & $(1)-(2)$ & $(1)$ & $(2)$ & $(1)-(2)$ \\
\hline & & $\checkmark$ & & & & \\
$1960 / 61$ & 160,174 & 67,214 & 92,960 & 120,972 & 46,850 & 74,122 \\
$1961 / 62$ & 1185,133 & 78,968 & 106,165 & 139,726 & 54,064 & 85,662 \\
$1962 / 63$ & 183,580 & 93,089 & 90,491 & 124,707 & 56,222 & 68,485 \\
$1963 / 64$ & 168,906 & 101,758 & 67,148 & 134,451 & 75,941 & 58,510 \\
$1964 / 65$ & 170,414 & 107,255 & 63,159 & 126,264 & 73,487 & 52,777 \\
$1965 / 66$ & 238,048 & 130,000 & 108,048 & 156,584 & 80,638 & 75,946 \\
$1966 / 67$ & 261,028 & 144,113 & 116,915 & 188,624 & 92,631 & 95,993 \\
$1967 / 68$ & 243,383 & 155,779 & 87,604 & 180,671 & 103,344 & 77,327 \\
$1968 / 69$ & 271,335 & 173,866 & 97,469 & 188,017 & 114,220 & 73,797 \\
$1969 / 70$ & 330,580 & 183,293 & 147,287 & 245,834 & 140,638 & 105,196 \\
\hline Total: & 2212,581 & 1235,335 & 977,246 & 1605,850 & 838,035 & 767,815 \\
\hline
\end{tabular}

Notes: 1. The figures do not include "foreign merchandise".

2. Values at domestic price are the published figures deflated by 5 percent to allow for freight and insurance.

3. The C.S.O. figure for 1968-69 covered from July to March, we made an upward adjustment to cover the remaining months of the financial year 1968/69.

Sources: $[4,5]$ 


\section{TABLE II}

\section{INTERWING EXPORTS OF FOREIGN MERCHANDISE}

(in thousand dollars)

\begin{tabular}{lccc}
\hline Years & $\begin{array}{c}\text { West Pakistan } \\
(1)\end{array}$ & $\begin{array}{c}\text { East Pakistan } \\
(2)\end{array}$ & $\begin{array}{c}\text { Balance } \\
(1)\end{array}$ \\
\hline $1960 / 61$ & 5,008, & 1,518 & 3,490 \\
$1961 / 62$ & 5,160 & 1,454 & 3,706 \\
$1962 / 63$ & 7,940 & 1,232 & 6,708 \\
$1963 / 64$ & 10,209 & 517 & 9,692 \\
$1964 / 65$ & 3,548 & 217 & 3,331 \\
$1965 / 66$ & 3,765 & 411 & 3,354 \\
$1966 / 67$ & 4,037 & 3,729 & 308 \\
$1967 / 68$ & 3,326 & 1,272 & 2,054 \\
$1968 / 69$ & 3,195 & 238 & 2,957 \\
$1969 / 70$ & 2,939 & 1,469 & 1,470 \\
Total: & 49,127 & 12,057 & 37,070 \\
\hline
\end{tabular}

Note: The values are at their actual prices (undeflated) and expressed in dollars by converting at the official exchange rate. 
TABLE III

INTERWING TRADE IN TERMS OF WORLD PRICES

(Commodities Exported from West Pakistan to East Pakistan) (in thousand dollars)

\begin{tabular}{|c|c|c|c|c|c|c|c|c|c|c|}
\hline Commodities & $1960 / 61$ & $1961 / 62$ & $1962 / 63$ & $1963 / 64$ & $1964 / 65$ & $1965 / 66$ & $1966 / 67$ & $1967 / 68$ & $1968 / 69$ & $1969 / 70$ \\
\hline $\begin{array}{l}\text { Cotton raw } \\
\text { Cotton twist and yarn } \\
\text { Cement } \\
\text { Rice } \\
\text { Wheat } \\
\text { Gram } \\
\text { Grain (other) } \\
\text { Cotton manufactures } \\
\text { Other manyfactured goods } \\
\text { Other primary goods. }\end{array}$ & $\begin{array}{r}17539 \\
21350 \\
159 \\
9842 \\
53 \\
1315 \\
676 \\
20905 \\
26848 \\
22285 \\
\end{array}$ & $\begin{array}{r}25493 \\
20274 \\
3092 \\
2250 \\
567 \\
1466 \\
773 \\
22421 \\
39407 \\
23983\end{array}$ & $\begin{array}{r}16869 \\
1771 \\
1527 \\
23893 \\
985 \\
1129 \\
2420 \\
22234 \\
33268 \\
20611\end{array}$ & $\begin{array}{r}16535 \\
20534 \\
538 \\
18385 \\
54 \\
833 \\
108 \\
20851 \\
33621 \\
22992\end{array}$ & $\begin{array}{r}15903 \\
9635 \\
3 \\
2387 \\
1147 \\
1566 \\
586 \\
24326 \\
46724 \\
23987\end{array}$ & $\begin{array}{r}10108 \\
8847 \\
1705 \\
20720 \\
8320 \\
2771 \\
927 \\
24312 \\
44108 \\
34766\end{array}$ & $\begin{array}{r}15494 \\
4169 \\
3289 \\
28489 \\
2056 \\
3903 \\
1241 \\
30505 \\
66231 \\
33247\end{array}$ & $\begin{array}{r}22907 \\
68 \\
4840 \\
21373 \\
36 \\
2577 \\
306 \\
24397 \\
55933 \\
48234\end{array}$ & $\begin{array}{r}25800 \\
3637 \\
3908 \\
8599 \\
1737 \\
2442 \\
799 \\
22245 \\
39166 \\
24074\end{array}$ & $\begin{array}{r}34206 \\
9166 \\
4190 \\
54202 \\
9134 \\
2298 \\
4894 \\
30323 \\
60805 \\
36616\end{array}$ \\
\hline Total & 120972 & 139726 & 124707 & 134451 & 126264 & 156584 & 188624 & 180671 & 132407 & 245834 \\
\hline
\end{tabular}

Source:-See Table I

$1067.241058 .34 \quad 999.51$

* The figures for $1968 / 69$ are from July 1968 to March 1969, $1157.921157 .251432 .441161 .28 \quad 1058.8621443 .37$ 1875.77153 .561600 .62224 .662099 .543152 .59266 .411564 .3022894 .22 2943.3 
TABLE IV

INTERWING TRADE IN TERMS OF WORLD PRICES

(Commodities Exported from East Pakistan to West Pakistan) (In thousand dollars)

\begin{tabular}{|c|c|c|c|c|c|c|c|c|c|c|}
\hline Commodities & $1960 / 61$ & $1961 / 62$ & $1962 / 63$ & $1963 / 64$ & $1964 / 65$ & $1965 / 66$ & $1966 / 67$ & $1967 / 68$ & $1968 / 69$ & $1969 / 70$ \\
\hline $\begin{array}{l}\text { Tea } \\
\text { Gunny bags } \\
\text { Gunny clothes } \\
\text { Hides and skins } \\
\text { Grains (other) } \\
\text { Jute products n.e.s. } \\
\text { Cotton manufactures } \\
\text { Other manufactured goods } \\
\text { Other primary commodities }\end{array}$ & $\begin{array}{r}16547 \\
6489 \\
1319 \\
160 \\
35 \\
897 \\
64 \\
16433 \\
4906\end{array}$ & $\begin{array}{r}11829 \\
10169 \\
1377 \\
97 \\
62 \\
1592 \\
195 \\
21373 \\
7370\end{array}$ & $\begin{array}{r}14633 \\
8099 \\
1973 \\
856 \\
5 \\
1007 \\
182 \\
21711 \\
7756\end{array}$ & $\begin{array}{r}19419 \\
19311 \\
3517 \\
115 \\
2 \\
1240 \\
144 \\
22336 \\
9857\end{array}$ & $\begin{array}{r}19314 \\
14998 \\
3091 \\
12 \\
4 \\
1399 \\
927 \\
26713 \\
7029\end{array}$ & $\begin{array}{r}17932 \\
18911 \\
4017 \\
2 \\
182 \\
1754 \\
490 \\
30623 \\
6727\end{array}$ & $\begin{array}{r}23868 \\
18179 \\
5730 \\
9 \\
328 \\
2200 \\
1987 \\
30886 \\
9444\end{array}$ & $\begin{array}{r}27335 \\
21007 \\
2532 \\
21 \\
49 \\
2360 \\
301 \\
42453 \\
7286\end{array}$ & $\begin{array}{r}22079 \\
14998 \\
4777 \\
6 \\
151 \\
2011 \\
259 \\
36162 \\
4796\end{array}$ & $\begin{array}{r}30006 \\
35578 \\
6190 \\
3 \\
4949 \\
2229 \\
201 \\
55179 \\
6303\end{array}$ \\
\hline Total: & 46850 & 54064 & 56222 & 75941 & 73487 & 80638 & 92631 & 103344 & 85239 & 40638 \\
\hline
\end{tabular}

* The figures for 1968-69 are from July 1968 to March 1969.

Source: See Table I. 


\section{REFERENCES}

1. Islam, Nurul, "Commodity Exports, Net Exchange Earnings and Investment Criteria", Pakistan Development Review, Winter 1968.

-2. Islam, Nurul, "Nature and Impact of Export Incentives and Effective Export Subsidy" PIDE Research Report No. 86, 1969.

3. Lewis, Stephen R. (Jr.) "Pakistan Industrialization and Trade Policies", OECD, 1970.

4. Pakistan, Central Statistical Office, "Statistical Year Book, 1968", Statistical Bulletins, 1969 and 1970.

5. Pakrstan, Central Statistical Office, "Foreign Trade Statistics of Pakistan, 1960-70.

6. Pakistan, Chief Controller of Imports and Exports, "Manual of Imports and Exports Control", Karachi, 1964.

2. Pakistan, Ministry of Food, and Agriculture, "Year Book of Agricultural Statistics", 1971-72, Islamabad, 1972.

- 8. Soligo, R. and Stern, J.J. "Some Comments on the Export Bonus, Export Promotion and Investment Criteria" Pakistan Development Review, 1966. 